FIU Law Review

Spring 2017

\title{
Florida Joins the Fight Against Revenge Porn: Analysis of Florida's New Anti-Revenge Porn Law
}

Diane Bustamante

Florida International University College of Law

Follow this and additional works at: https://ecollections.law.fiu.edu/lawreview

Part of the Criminal Law Commons, and the State and Local Government Law Commons

Online ISSN: 2643-7759

\section{Recommended Citation}

Diane Bustamante, Florida Joins the Fight Against Revenge Porn: Analysis of Florida's New Anti-Revenge Porn Law, 12 FIU L. Rev. 357 (2017).

DOI: https://dx.doi.org/10.25148/lawrev.12.2.9

This Comment is brought to you for free and open access by eCollections. It has been accepted for inclusion in FIU Law Review by an authorized editor of eCollections. For more information, please contact lisdavis@fiu.edu. 


\title{
Florida Joins the Fight Against Revenge Porn: Analysis Of FloridA's NeW ANTi-Revenge Porn LAW
}

\author{
Diane Bustamante*
}

\section{INTRODUCTION}

While many refer to widespread commotion on the internet as "breaking the internet," the internet "nearly exploded" on August 31, 2014, when dozens of female celebrities, including Jennifer Lawrence, Ariana Grande, and Kim Kardashian, became the victims of non-consensual pornography as their personal, nude photographs were leaked on a website called 4chan.org. ${ }^{1}$ Hackers effectuated their "targeted attack" after gaining access to the celebrities' iCloud login credentials. ${ }^{2}$ Not more than six weeks later, nearly 100,000 user photographs from the "Snapchat" app were leaked on Viralpop.com and later on 4chan.org. ${ }^{3}$ Even more troubling is that the leak included nude photographs of minors because Snapchat's primary audience is teenagers between the ages of thirteen and seventeen. ${ }^{4}$

For the most part, people are familiar with the concept of nonconsensual pornography, commonly known as "revenge porn" (used interchangeably throughout this Comment), to the extent it has been publicized in the media in cases such as those mentioned above. ${ }^{5}$ Despite its name, "revenge porn" is not always revenge-driven. ${ }^{6}$ Beyond revenge,

\footnotetext{
* Esq. Florida International University College of Law, J.D., May 2016; B.A. 2010. I want to thank God; the FIU LAW REVIEW for their efforts in preparing this Comment for publication; my faculty advisor, Professor Carpenter, for his guidance and insight; my husband, Daniel Bustamante, for his daily encouragement and faith in me; and my family for their continuous love and support in all my endeavors.

1 Laurele O'Connor, Celebrity Nude Photo Leak: Just One More Reminder that Privacy Does Not Exist Online and Legally, There's Not Much We Could Do About It, Golden GATE U.L. REV. ONLINE (Oct. 21, 2014), http://ggulawreview.org/2014/10/21/celebrity-nude-photo-leak-just-one-morereminder-that-privacy-does-not-exist-online-and-legally-theres-not-much-we-can-do-about-it-2/.

2 Id.

3 Id. Snapchat is photograph and video-messaging application ("app") that launched in 2011. It enables a user to take a photograph or brief video, add a caption or filter over the top, then send the finished product (called a snap) to his or her friends. The app is unique in that snaps may last only for up to 10 seconds, permanently self-destructing once the person receiving the snap views it. As of May 2014, the app's users were sending 700 million snaps a day. Elyse Betters, What's the Point of Snapchat and How Does it Work?, POCKET-LINT (Jan. 20, 2017), http://www.pocketlint.com/news/131313-what-s-the-point-of-snapchat-and-how-does-it-work.

4 O’Connor, supra note 1.

5 See id.

6 Janelle Griffith, Revenge Porn: Well-known Celebrity Victims, NJ.COM (Jan. 9, 2015, 9:12 AM), http://www.nj.com/entertainment/index.ssf/2015/01/celebrity_revenge_porn_victims.html.
} 
"sexual and intimate images are being used to coerce, threaten, harass and abuse victims."7 Revenge porn has occurred not only by the hands of hackers, but by "ex-partners or so-called friends," and many times outside of the known revenge porn websites. ${ }^{8}$ While as many as 3,000 websites currently feature "revenge porn," intimate pictures and videos are also commonly distributed without consent through other channels such as "social media, blogs, e[-]mails, and texts." Revenge porn has grown so exponentially that websites have been created to cater to any specific motive, such as ShesAHomewrecker.com where wives can "share photos of the women who they suspect are their husband's lovers." ${ }^{\text {"10 }}$ While there may be different circumstances surrounding these instances, the victims of these cruel acts share a common harm - not only embarrassment but longterm psychological damage, including "sexual shame, disruption to their education or employment, and trust issues."

Without laws explicitly criminalizing revenge porn, victims have little to no remedy in the law. ${ }^{12}$ Currently, twenty-six states have enacted specific laws criminalizing nonconsensual pornography. ${ }^{13}$ Although legislators nationwide have recently reacted to the growing epidemic, existing anti-harassment laws fail to provide victims with an adequate remedy in states where revenge porn has not been explicitly named as an offense. $^{14}$ In other words, "If you're Jennifer Lawrence, you can pay a high-priced lawyer to demand that websites take your picture down, but for an average person, the current system offers almost no recourse." 15

7 Nicola Henry et al., How the Law Can Help End 'Revenge Porn', LA Trobe U. (Feb. 19, 2016), http://www.latrobe.edu.au/news/articles/2016/opinion/how-the-law-can-help-end-revenge-porn.

8 Nina Bahadur, Victims of 'Revenge Porn' Open up on Reddit About How it Impacted Their Lives, HUFFINGTON POST (Jan. 10, 2014, 8:50 AM), http://www.huffingtonpost.com/2014/01/09/revenge-porn-stories-real-impact_n_4568623.html; see also Kashmir Hill, This Guy Hunts Down the Men Behind Revenge Porn Websites, ForBES, (Apr. 23, 2014),

https://www.forbes.com/sites/kashmirhill/2014/04/23/this-guy-hunts-down-the-men-behind-revengeporn-websites/\#2e4c7c5f6c7b (naming several revenge porn websites such as Texxan, YouGotPosted, WinByState, and IsAnyoneUp).

9 Mary Anne Franks, The Fight Against Digital Abuse: The View from the US by Mary Anne Franks, WOMEN'S AID (Dec. 15, 2015, 12:25 PM), https:/www.womensaid.ie/16daysblog/2015/12/15/ the-fight-against-digital-abuse-the-view-from-the/.

10 Revenge Porn and Its Victims, NobUlLying.COM (Dec. 22, 2015), http://nobullying.com/revenge-porn/.

11 Bahadur, supra note 8.

12 See Inside the Torturous Fight to End Revenge Porn, BroAdLY (Feb. 3, 2016), https://broadly.vice.com/en_us/video/inside-the-torturous-fight-to-end-revenge-porn.

13 Id.

$14 \quad I d$.

15 Williams Pelegrin, Revenge Porn Could Soon Become a Federal Crime in the United States, Digital TRENDS (Feb. 25, 2015, 12:09 PM), http://www.digitaltrends.com/computing/national-revengeporn-bill-could-be-a-law/\#ixzz41hrPFkD4. 
Because revenge porn only recently became a topic considered for criminalization, many state laws that $d o$ address nonconsensual pornography fall short of being strong, comprehensive laws, Florida's new law being one of them. Florida recently passed an anti-revenge porn law, section 784.049, Florida Statute (2015), titled "Sexual cyberharassment," which took effect on October 1, 2015 ("Section 784.049"). Florida became the sixteenth state to join the movement toward outlawing revenge porn. ${ }^{16}$ While the statute is surely a step in the right direction, it needs reform. First, this Comment will discuss the history of revenge porn and its evolution alongside technological advances, including social media. Second, this Comment will explore the harm revenge porn causes to its victims and the need for aggressive laws to combat it. Third, it will discuss the controversy surrounding the criminalization of revenge porn, including the heavily debated First Amendment concerns that arise as states enact laws combating revenge porn across the country, as well as the arguments proponents of the laws have made defending the laws' constitutionality. Fourth, this Comment will discuss Florida's failed revenge porn bills and why they failed. Fifth, this Comment will analyze the current Florida law on point and discuss in detail its strengths and weaknesses. Finally, this Comment will analyze Illinois's revenge porn law titled, "Non-consensual dissemination of private sexual images," and suggest it as a model statute for Florida legislators to use in amending Florida's current law.

\section{BACKGROUND}

\section{REVENGE PORN: What IS IT?}

Non-consensual pornography can be generally defined as "the distribution of sexually graphic images of individuals without their consent." 17 Such images include those "originally obtained without consent (e.g. hidden recordings or recordings of sexual assaults)" or those "images originally obtained with consent, usually within the context of a confidential relationship (e.g. images consensually given to an intimate partner who later distributes them without consent).",18

16 Elisa D'Amico, As Florida's Sexual Cyberharassment Law Becomes Effective, Thinking About Corporate Social Responsibility, MiAMi HERALD, (Sept. 27, 2015, 3:00 PM), http://www.miamiherald.com/news/business/biz-monday/article36653298.html.

17 Danielle Keats Citron \& Mary Anne Franks, Criminalizing Revenge Porn, 49 WAKE FOREST L. REV. 345, 346 (2014).

18 Id. 


\section{HISTORY OF REVENGE PORN}

While access to pornography has depended on technology for over forty-five years, the internet has taken it to a new level making it not only easier to view pornography at any time, especially with smartphones, but also "eas[ier] and more appealing for people to create and distribute Do-ItYourself pornography." 19 With the increased use of smartphones, came the increase in "sexting." 20 Sexting is "receiving, sending, or forwarding sexually suggestive photos or videos via cell phones." 21 In fact, according to a study conducted by Pew Research Center in 2013, 9\% of cell phone users "have sent a sexual picture or video, while $20 \%$ have received one," an increase from 2012 when only $6 \%$ of cell owners had sent a sext and $15 \%$ had received one. ${ }^{22}$

For many, the concept of revenge porn was introduced in 1980 with the case Wood v. Hustler Magazine. ${ }^{23}$ In Wood, a married couple was camping in a state park. ${ }^{24}$ They were walking alone in the wilderness when they became hot, took off their clothes, and went swimming in a river. ${ }^{25}$ The couple then took naked pictures of each other, which the husband later developed and kept in a private space in their home. ${ }^{26}$ A neighbor broke into the couple's home, stole some of the private photographs, and eventually submitted a naked photograph of the woman, LaJuan, to Hustler Magazine for publication in its "Beaver Hunt" section. ${ }^{27}$

Typically, Hustler Magazine readers contributed to the "Beaver Hunt" column by sending naked photographs of "nonprofessional female "models.", 28 The "models" received a fifty dollar fee if their photograph(s) were selected for publication. ${ }^{29}$ The publication required a consent form requesting personal information, which the neighbor completed partially

19 Taylor Linkous, It's Time for Revenge Porn to Get a Taste of its Own Medicine: An Argument for the Federal Criminalization of Revenge Porn, 20 RiCH. J.L. \& TECH. 14, 5 (2014). In 2015, the number of Pornhub's users who opted for smartphones and tablets when visiting Pornhub significantly increased. "In fact, visits from smartphones alone now account for 53\% of traffic shares, up from just 45\% last year." Pornhub's 2015 Year in Review, PoRnHUB (Jan. 6, 2016), http://www.pornhub.com/insights/pornhub-2015-year-in-review.

20 Linkous, supra note 19.

21 Amanda Lenhart \& Maeve Duggan, Couples, the Internet, and Social Media: Main Report, PEW RES. CENT. (Feb. 11, 2014), http://www.pewinternet.org/2014/02/11/main-report-30/.

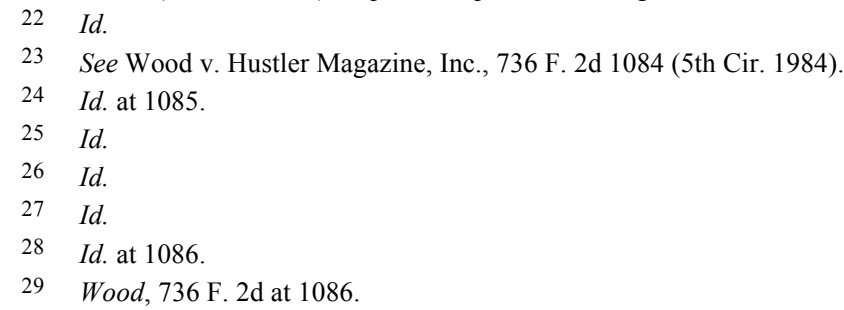


truthfully, by including the victim's correct identity; and partially falsely, by stating the victim had a fantasy of being "tied down and screwed by two bikers." ${ }^{30}$ The neighbor's wife then forged the victim's signature. ${ }^{31}$ Hustler Magazine did not have any formalized, written policies and procedures to guard against stolen photographs or to fully ensure that the information submitted was accurate and, in fact, with the consent of the owner of the photograph(s) to be published. ${ }^{32}$ It did, however, have an informal policy designed to confirm the information on the consent form but it was by no means fool-proof. ${ }^{33}$

Hustler Magazine published the nude photograph of LaJuan in Hustler Magazine's February 1980 issue with the caption, "Photo by Husband." 34 The publication also stated, "Lajuan Wood is a 22-year old housewife and mother from Bryan, Texas, whose hobby is collecting arrowheads. Her fantasy is "to be screwed by two bikers.",35 The victims, husband and wife, became aware of the publication from their friends and, in disbelief that a nude photograph of LaJuan had been published in a magazine, the couple obtained a copy of the issue to see it for themselves. ${ }^{36}$ As a result, LaJuan suffered mental and emotional conditions, such as humiliation, degradation, and embarrassment. ${ }^{37}$ She was even harassed with various obscene telephone calls after the publication. ${ }^{38}$ LaJuan required psychological counseling for over six weeks to cope with the psychological repercussions of what had occurred. ${ }^{39}$

By the 2000s, only twenty years after what many would consider the introduction of revenge porn, it was referred to as "an emergent genre" labeled "realcore pornography." In 2008, Xtube, the first website to provide a platform allowing both registered and unregistered users to share adult videos, ${ }^{41}$ stated it was receiving multiple complaints a week due to

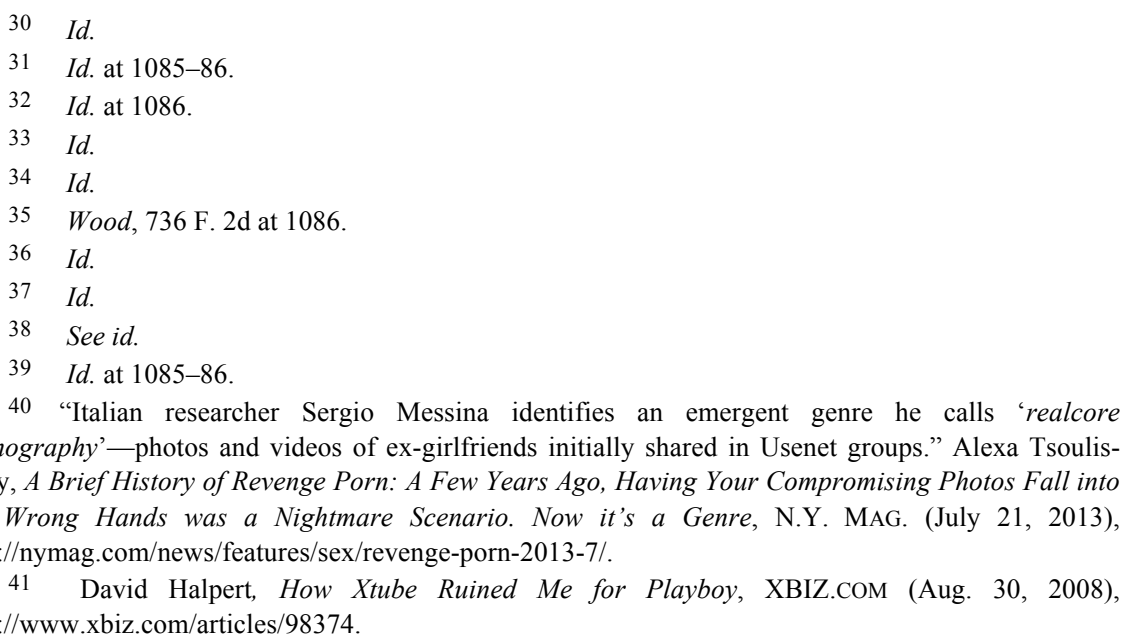
http://www.xbiz.com/articles/98374. 
revenge porn on its website. ${ }^{42}$ At that time, websites specifically created for the purpose of exploiting non-consensual pornography, such as RealExgirlfriends.com and IKnowThatGirl.com, spearheaded the giant industry we face today. ${ }^{43}$

Not surprisingly, by 2009 , revenge porn had hit social media. ${ }^{44}$ During the time when Facebook had an audience of 200 million users ${ }^{45}$ Holli Jacobs, now a civil rights activist, became a victim of revenge porn. ${ }^{46}$ Jacobs and her then-boyfriend, Ryan Seay, dated in 2005, and eventually were in a long distance relationship in which they shared photographs "to keep the intimacy alive." 47 Jacobs said she "completely trusted him." ${ }^{, 48}$ In 2008, they broke up in what she referred to as a "normal breakup."49 However, on January 1, 2009, Jacobs received a horrifying call from her friend who said that "[Jacobs] need[ed] to get on Facebook right away" because someone had changed her profile picture to a nude picture of her. ${ }^{50}$ Jacobs called Seay immediately, as she claims he "was the only one with those photos," but he denied involvement. ${ }^{51}$ He allegedly posted photographs and a video, which even her university bosses received in an email titled "Masturbation 201 by Professor Holli Thometz," Jacobs's thenlast name. ${ }^{52}$ Jacobs faced an uphill battle trying to get websites to remove her photographs. ${ }^{53}$ Even after being removed, they would reappear within a week. ${ }^{54}$

Eventually, Holli Jacobs abandoned her attempts to remove the content, changed her last name, and sought a remedy in the law. ${ }^{55}$ Specifically, Jacobs contacted the City of Miami and Miami-Dade County Police Department, but was told that "because she was over 18 and Seay

42 Tsoulis-Reay, supra note 40.

43 Id.

44 Michael E. Miller, Revenge Porn Victim Holly Jacobs "Ruined my Life," Ex Says, MIAMI NEW TIMES (Oct. 17, 2013, 4:00 AM), http://www.miaminewtimes.com/news/revenge-porn-victimholly-jacobs-ruined-my-life-ex-says-6393654.

45 Stan Schroeder, The Web in Numbers: The Rise of Social Media, MASHABLE (Apr. 17, 2009), http://mashable.com/2009/04/17/web-in-numbers-social-media/\#UvZ1_tQhWSq9.

46 Michael E. Miller, Miami Student Holly Jacobs Fights Revenge Porn, MiAmi New TimeS (May 9, 2013, 4:00 AM), http://www.miaminewtimes.com/news/miami-student-holly-jacobs-fightsrevenge-porn-6392040.

$\begin{array}{ll}47 & I d . \\ 48 & I d . \\ 49 & I d . \\ 50 & I d . \\ 51 & \text { See id. } \\ 52 & I d . \\ 53 & I d . \\ 54 & I d . \\ 55 & I d .\end{array}$


hadn't technically stolen the photographs, there was nothing they could do." ${ }^{, 56}$ In other words, because she technically consented to his possession of the pictures initially, and because there was no effective legal recourse for revenge porn in Florida, Seay's actions, and the harm he caused as a result, would go without consequence. ${ }^{57}$

In 2010, IsAnyoneUp.com launched and encouraged revenge porn by featuring not only naked photographs submitted by spiteful ex-lovers, but also the pictured person's full name, profession, city of residence, and snapshot of their social media profile alongside the photograph, which ensured the pictures would emerge upon a Google search. ${ }^{58}$ The infamous Hunter Moore, the creator of this website, who referred to himself as the "professional life ruiner," 59 even taunted victims on the website with statements like, "We've all masturbated to you or laughed at you ... [i]t can't get any worse." $" 60$ While Facebook eventually ordered Moore to remove all Facebook-related content from the website, claiming his actions violated Facebook's terms of service, and also deleted his profile, Moore's website lasted for two years aiding in the victimization of countless people. ${ }^{61}$ While Moore took down the website in 2012, which made him up to $\$ 13,000$ per month, ${ }^{62}$ he was eventually arrested for hiring a hacker "who illicitly accessed e-mail accounts in order to steal nude photos." 63 Because revenge porn is not illegal in the United States, Moore was charged and pled guilty to two charges unrelated to revenge porn itself: one count of unauthorized access to a protected computer to obtain information for purposes of private financial gain and one count of aggravated identity theft. $^{64}$ Moore was sentenced to two and a half years in federal prison, ordered to pay a $\$ 2,000$ fine and an additional $\$ 145.70$ to a single victim in restitution, ordered to undergo a mental health evaluation, and sentenced to

$56 \quad I d$.

57 See id.

58 Alex Morris, Hunter Moore: The Most Hated Man on the Internet, RoLLING STONE (Nov. 13, 2012), http://www.rollingstone.com/culture/news/the-most-hated-man-on-the-internet-20121113\#ixzz3s GCORwmJ.

59 Emily Zemler, Naked \& Famous: How a Risque New Website Pushes Boundaries and Buttons, AlternATIVE PRESS (Feb. 14, 2011, 9:00 AM), http://www.altpress.com/features/entry/naked _famous_how_a_risque_new_website_pushes_boundaries_and_buttons.

60 Tsoulis-Reay, supra note 40.

61 Kashmir Hill, IsAnyoneUp Is Now Permanently Down, ForBes (Apr. 19, 2012, 5:52 PM), http://www.forbes.com/sites/kashmirhill/2012/04/19/isanyoneup-is-now-permanently-down/.

62 Id.

63 Abby Ohlheiser, Revenge Porn Purveyor Hunter Moore is Sentenced to Prison, WASH. PosT (Dec. 3, 2015), https://www.washingtonpost.com/news/the-intersect/wp/2015/12/03/revenge-pornpurveyor-hunter-moore-is-sentenced-to-prison/.

$64 I d$. 
three years of supervised release after serving his sentence. ${ }^{65}$

Similarly, in June 2014, "a cyberbullying suspect solicited sexually explicit Snapchat photos of Brevard County high school girls, then posted them on an Instagram account - alongside the girls' names and the names of their schools." ${ }^{\prime 66}$ However, there was no Florida law criminalizing "revenge porn" under which to file charges against the suspect. ${ }^{67}$

\section{THE HARM AND NEED FOR LEGISLATION}

While non-consensual pornography is called "revenge porn," the title is not only misleading, but also grossly undermines its effects, as it fails to describe the mental torture it causes victims. ${ }^{68}$ It is true that many cases involve a vengeful, malicious perpetrator whose purpose is to harm his ex by blasting her most intimate photographs to the public for all to see. ${ }^{69}$ However, many perpetrators have never met their victims at all and, as such, can have other motives such as "entertainment, profit[,] or notoriety," $" 70$ expanding the pool of potential victims significantly.

Victims of revenge porn suffer harm each time their pictures are viewed, often by thousands, sometimes even millions. ${ }^{71}$ As one victim explained:

[A]s a victim of [r]evenge [p]orn, I am not victimized one time. I am victimized every time someone types my name into the computer. The crime scene is right before everyone's eyes, played out again and again, and, ironically, I am treated as if I am the one who has committed the crime. I am victimized every time someone tells me that it's my fault because I consented to the taking

65 Lane Moore, The Most Hated Man on the Internet is Finally Going to Jail. Not for Long Though., CosmopolitAN (Dec. 4, 2015), http://www.cosmopolitan.com/sex-love/news/a50313/revengeporn-jail-time/; Sarah Jeong, Hunter Moore Revenge Porn Victim Got a Whopping \$145.70 in Restitution, MOTHERBOARD (Dec. 3, 2015, 5:05 PM), https://motherboard.vice.com/en_us/article/hunter -moore-revenge-porn-victim-got-a-whopping-14570-in-restitution.

66 Rob Beschizza, Even Florida has a Revenge Porn Law Now, BoINGBoIng (May 29, 2015, 7:52 PM), http://boingboing.net/2015/05/29/even-florida-has-a-revenge-por.html.

67 Id.

68 See generally Miller, supra note 46.

69 See Mary Anne Franks, How to Defeat 'Revenge Porn:' First, Recognize It's About Privacy, Not Revenge, HuFfington PosT (June 22, 2015, 8:22 AM), http://www.huffingtonpost.com/mary-annefranks/how-to-defeat-revenge-porn_b_7624900.html.

70 Mary Anne Franks, Why Revenge Porn Must be a Crime: Dissecting Critics' Attempts to Nitpick Important Legislation, N.Y. DAILY NEws (Feb. 26, 2014, 3:03 PM), http://www.nydailynews. com/opinion/revenge-porn-crime-article-1.1702725.

71 Taylor E. Gissell, Felony Count 1: Indecent Disclosure, 53 Hous. L. REV. 273, 283 (2015). 
of the photos. $^{72}$

Aside from the mass exposure the images are subject to once introduced to the universe that is the internet, the images can be e-mailed or exhibited to the victim's family, employers, co-workers, and friends by other means. ${ }^{73}$ Thus, victims of revenge porn are not only exposed physically through their nude photographs, but the exposure of their demographical and other personal information that usually comes with it makes them susceptible to stalking and places them in danger. ${ }^{74}$ This can lead to a victim's fear of being alone or feeling unsafe when leaving their house. $^{75}$

Victims of non-consensual pornography most likely encounter loss of their current employment and future employment opportunities. ${ }^{76}$ An U.S. Department of Transportation employee, for example, was fired after her co-workers sent a naked picture of her to her colleagues. ${ }^{77}$ Similarly, victims are often fired or eliminated as candidates for potential positions because revenge porn websites often link the photographs to the person depicted through identifying information; therefore, the photographs appear when the name is searched on a search engine by either current or potential employers. ${ }^{78}$ Teachers have been fired by their school's administration after discovering that the teachers' naked pictures were posted on the internet. ${ }^{79}$ According to one study by Microsoft in 2009, "more than $80 \%$ of employers rely on potential employees' online reputations as an employment screen," $70 \%$ of the time rejecting applicants based on their findings; ${ }^{80}$ these numbers are surely to have increased as society has become even more "google-obsessed" in recent years. ${ }^{81}$ Unfortunately, when recruiters come across nude photographs of potential employees, they

72 Aja Romano, Revenge Porn Isn't Illegal Everywhere, but Victims Can Still Fight Back, DAILY DoT (Oct. 16, 2013, 7:00 AM), http://www.dailydot.com/crime/revenge-porn-how-to-fight-back/.

73 Citron \& Franks, supra note 17, at 350.

74 See id.

75 Id. at 351.

$76 \quad$ Id. at 352

77 Daniel Castro \& Alan McQuinn, Why and How Congress Should Outlaw Revenge Porn, INFO. TECH. \& INNOVATION FOUND. 1, 2 (July 2015), https://itif.org/publications/2015/07/15/why-and-howcongress-should-outlaw-revenge-porn.

78 See Sarah Bloom, No Vengeance for 'Revenge Porn' Victims: Unraveling Why This Latest Female-Centric, Intimate-Partner Offense is Still Legal, and Why We Should Criminalize It, 42 FORDHAM URB. L.J. 233, 240-41 (2014).

79 Citron \& Franks, supra note 17, at 352.

80 Id.; see also Danielle Keats Citron, 'Revenge Porn' Should be a Crime in U.S., CNN.COM (Jan. 16, 2014, 3:49 PM), http://www.cnn.com/2013/08/29/opinion/citron-revenge-porn/.

81 See generally Biz Carson, More People Now Search Google on Their Phone than From Their Computers, BUS. INSIDER (Oct. 8, 2015, 1:38 PM), http://www.businessinsider.com/more-people-nowsearch-google-on-their-phone-than-from-their-computers-2015-10. 
do not contact the victims to inquire whether victims posted the nude photographs themselves or whether someone else did in violation of their trust and privacy. ${ }^{82}$ The "simple but regrettable truth is that after consulting search results, employers don't call revenge porn victims to schedule' interviews or to extend offers." ${ }^{" 83}$ Put simply, employers, in looking out for their companies' best interest, refuse to hire candidates "whose search results might reflect poorly on the employer." 84 For many of these same reasons, victims of revenge porn also frequently suffer loss of educational opportunities. ${ }^{85}$

An even graver problem is the psychological harm victims experience as a result of the abrupt invasion of their sexual privacy. ${ }^{86}$ Victims of revenge porn have to deal with not only their own feelings of humiliation, shame, and deceit, but also society's wrath and condemnation through the common practice of victim-blaming. ${ }^{87}$ Rather than placing the blame on the perpetrator, the focus is on the women, who are being scorned, objectified, and demoralized for taking nude pictures of themselves, or for allowing someone else to take the pictures in the first place. ${ }^{88}$ As one police officer put it, "People just have to grow up in terms of what they're taking and loading on to the computer because the risk is so high. [They say] if you go out in the snow without clothes on you'll catch a cold - if you go on to the computer without your clothes on, you'll catch a virus." $\$ 89$

In general, revenge porn victims become increasingly more susceptible to committing suicide. ${ }^{90}$ According to a Cyber Civil Rights Initiative survey, fifty-one percent of revenge porn victims experienced suicidal thoughts. ${ }^{91}$ As one victim of a revenge porn website that posted nude photographs of her along with her information said, "she was so traumatized by the experience she tried to commit suicide." "92 Another

82 Citron \& Franks, supra note 17, at 352.

Id.

Id.

Id. at 347.

See generally Bloom, supra note 78, at 241.

See Revenge Porn and Its Victims, supra note 10.

Id.

89 'Grow Up' and Stop Taking Naked Photos of Yourself, Police Tell Revenge Porn Inquiry, GUARDIAN (Feb. 18, 2016, 2:12 AM), http://www.theguardian.com/australia-news/2016/feb/18/growup-and-stop-taking-naked-photos-of-yourself-says-senior-police-officer.

90 See generally Bloom, supra note 78, at 240.

91 "Survey results were achieved from a survey that was hosted on endrevengeporn.org from August 2012-Dec 2013. Participants self-selected into the study by visiting our websites and filling out the survey on their own accord. Results depicted are reflective of a female-heavy sample, due to most of our site visitors being women." End Revenge Porn Survey, CyBER C.R. InITIATIVE (2014), https://www.cybercivilrights.org/ncpstats/.

92 Candice Nguyen, Victims of "Revenge Porn” Cyber Exploitation “Find Justice," NBC SAN 
victim considered suicide after a man she slept with once became obsessed, sent her messages from sixty-seven different Facebook accounts, and sent a video of them having sex to her daughter. ${ }^{93}$ Unfortunately, many victims have not just contemplated suicide, but have actually ended their life, like Tyler Clementi. ${ }^{94}$

[Just] [t]hree weeks into his first semester at Rutgers University, Clementi asked his roommate for some privacy in their shared room for the night. Clementi's roommate, eighteen-year-old Dharun Ravi, left the room but set up his laptop in order to spy on Clementi's date. Ravi discovered that Clementi was using the room to have a sexual relationship with another man and [Ravi] solicited his Twitter followers to watch the live stream of the video proof. Hours after this information was posted, Clementi jumped off the George Washington Bridge to his death. ${ }^{95}$

\section{CONTROVERSY OVER CRIMINALIZING REVENGE PORN}

Recognizing the grave harm revenge porn causes its victims and society as a whole, some states have already criminalized revenge porn and many are currently considering legislation. ${ }^{96}$ However, there is an ongoing debate regarding whether criminalization is warranted and, if so, whether it is the "be-all and end-all" solution to revenge porn. ${ }^{97}$ Opponents of revenge porn laws argue that there are already civil remedies in place that can provide victims with other avenues to seek legal recourse, which proponents argue is not really the case for several reasons. ${ }^{98}$ Also, opponents argue that it is too difficult "to properly draft a law that is not either over-inclusive or under-inclusive in its scope." $"$ Another heavily debated issue is the argument that revenge porn is protected speech under the First Amendment and, therefore, laws banning revenge porn are

DiEGo (Apr. 4, 2015, 12:59 PM), http://www.nbcsandiego.com/news/local/Victims-of-Revenge-PornExploitation-Website-Find-Justice-298672821.html.

93 Josh Layton \& Elle Griffiths, 'I Considered Suicide': Revenge Porn Victim Opens up After

Jilted Lover Sent Sex Pics to Her Daughter, MIRror (Apr. 5, 2015 12:41 PM), http://www.mirror.co.uk/news/uk-news/i-considered-suicide-revenge-porn-5462446.

94 Gissell, supra note 71 , at 280.

95 Id. at $280-81$.

96 Justine Larsen, Criminalizing Revenge Porn: The Debate, OHIO ST. U. АмICI BLOG, http://moritzlaw.osu.edu/students/groups/osjcl/amici-blog/criminalizing-revenge-porn-the-debate/.

97 Id.

98 See generally id.

$99 \quad I d$. 
unconstitutional. ${ }^{100}$ Finally, opponents argue that even if laws criminalizing nonconsensual pornography were passed, prosecuting under these statutes "would cause more harm than good."

\section{INSUFFICIENT OR UNREALISTIC REMEDIES}

Opponents argue that a revenge porn victim has options: he or she can go after the perpetrator for invasion of privacy, harassment, stalking, intentional infliction of emotional distress, or under a tort theory of public disclosure of private information. ${ }^{102}$ Furthermore, a victim who personally took the photographs (i.e. "selfies") later posted on a revenge porn website holds copyright in them and, through the Digital Millennium Copyright Act ("DMCA"), can, in theory, demand that they be taken down. ${ }^{103}$

On the other hand, proponents for criminalization of revenge porn argue that many civil remedies are not only insufficient or unrealistic, but also counterintuitive in terms of their supposed redress for the harm victims suffer. ${ }^{104}$ "The irony of privacy actions is that they generally require further breaches of privacy to be effective," which only adds to the victim's harm. ${ }^{105}$ Another obstacle victims face when bringing tort claims is the issue of which party to sue. ${ }^{106}$ It is not always the case that victims know by who or how the revenge porn was accessed and distributed; even if they do, they usually lack sufficient evidence to prove it in court or the perpetrator lacks the financial resources to make a claim for damages worthwhile. ${ }^{107}$ In such cases, while the commonsensical approach is, seemingly, to sue the owner of the website, Section 230 of the Communications Decency Act ("CDA") is likely to render any attempt to do so unsuccessful. ${ }^{108}$ CDA Section 230 provides website owners and hosts broad immunity for any tortious material submitted by third-party users, as they are not treated as the "publisher or speaker of any information provided by another information content provider."109

$100 \quad I d$

$101 \quad I d$.

102 Id: Sarah Jeong, Revenge Porn Is Bad. Criminalizing It Is Worse, WIRED (Oct. 28, 2013, 9:30 AM), http://www.wired.com/2013/10/why-criminalizing-revenge-porn-is-a-bad-idea/.

103 Revenge Porn Is Bad. Criminalizing It Is Worse, supra note 102.

104 See Larsen, supra note 96.

105 Mary Anne Franks, Why We Need a Federal Criminal Law Response to Revenge Porn, CONCURRING OPS. (Feb. 15, 2013), https://concurringopinions.com/archives/2013/02/why-we-need-afederal-criminal-law-response-to-revenge-porn.html.

106 Id.

107 See id.

108 Id.

109 Id. 
Victims who themselves photographed the images that are later posted by someone else without the victims' consent may also assert their rights under the DMCA. ${ }^{110}$ Because the victims own the copyright of the photographs, they can send a notice to the website to take it down and, if the website refuses to do so, the victims can sue the website for copyright infringement. ${ }^{111}$ While the victims' immediate goal is to have the private content removed from the internet, and copyright law may ultimately attain this goal, "a victim must publicly register" the very photograph(s) that he or she wants to remove from the public eye within ninety days of the website publishing it. ${ }^{112}$ Besides the contradictory nature of this recourse, it does not benefit victims who did not take the private photographs themselves, as only the taker of the photograph has the copyright, and therefore access to this remedy. ${ }^{113}$

Supporters of legislation combating revenge porn also argue that, even assuming a suit is successful and the private images are removed, the victim's harms would not have been fully remedied. ${ }^{114}$ The problem is that "there's literally nothing to stop the hundreds of other people that have already downloaded or re-posted [the] image."115 In other words, the damage has been done.

\section{NEED FOR EFFECTIVE DRAFTING}

Opponents of revenge porn laws argue that both an effective and narrowly tailored law is too difficult to achieve because of the ambiguity "surrounding what exactly constitutes revenge porn" and clearly defining its boundaries. ${ }^{116}$ Because the internet, by definition, is such a broad universe of easily accessible information "very little on the web exists in isolation from the rest: content is regularly copied, mimicked, modified, and linked to." 117 Accordingly, revenge porn laws run the risk of being overbroad and consequently, having unintended repercussions. ${ }^{118}$ For instance, while the

110 Hope Robertson, The Criminalization of Revenge Porn, CAMPBELL L. OBSERVER (July 21, 2015), http://campbelllawobserver.com/the-criminalization-of-revenge-porn/.

111 Id.

112 Larsen, supra note 96 (quoting Matthew Goldstein, Law Firm Founds Project to Fight 'Revenge Porn', N.Y. TiMES (Jan. 29, 2015, 7:47 PM), http://dealbook.nytimes.com/2015/01/29/lawfirm-founds-project-to-fight-revenge-porn/).

113 See Why We Need a Federal Criminal Law Response to Revenge Porn, supra note 105.

114 Larsen, supra note 96.

115 Why Revenge Porn Must be a Crime: Dissecting Critics' Attempts to Nitpick Important Legislation, supra note 70.

116 Larsen, supra note 96.

117 Revenge Porn Is Bad. Criminalizing It Is Worse, supra note 102.

118 Id. 
goal may be to go after the spiteful ex-boyfriend who uploaded his exgirlfriend's private images, revenge porn laws may unintentionally "sweep" the more innocent conduct, such as prosecuting and even convicting "a reporter [for] publishing screencaps of Anthony Weiner's more infamous tweets." $" 19$ The opposite is also true. ${ }^{120}$ Drafting a criminal statute too narrowly can create issues of under-inclusiveness by essentially failing to embrace certain forms of revenge porn, defeating the purpose of criminalization as it leaves many victims without legal recourse. ${ }^{121}$ As one opponent stated, a law that does not include "selfies" or liability for website owners and operators, for example, "is little more than lip service to the harm suffered by victims." $" 122$

Proponents, on the other hand, argue that an effective, enforceable statute could be drafted by including specific carve-out provisions to avoid overbreadth - the criminalization of innocent conduct, alongside provisions that ensure all victims have protection under the law. ${ }^{123}$ For example, statutes should include provisions specifying that "the dissemination of images voluntarily captured in public or commercial settings" and "disclosures made for legitimate purposes, such as the reporting of unlawful conduct or matters in the public interest" are not to be criminalized. ${ }^{124}$ Proponents also argue that statutes should concentrate on the victims' lack of consent - whether the victim consented to the distribution of the private material - in order to ensure all intended victims are covered under the statute. $^{125}$

\section{OVERCOMING FIRST AMENDMENT HURDLES}

While revenge porn laws are viewed as a breakthrough in legislation by many, critics of these laws have opposed both state proposals and federal legislation by claiming that such laws infringe on the right to freedom of speech, provided under the First Amendment of the Constitution. ${ }^{126}$ The First Amendment provides that "Congress shall make no law ... abridging the freedom of speech, or of the press." ${ }^{.27}$ In essence, the First Amendment

119 Larsen, supra note 96 (quoting Revenge Porn Is Bad. Criminalizing It Is Worse, supra note 102).

120 Id

121 Id.

122 Revenge Porn Is Bad. Criminalizing It Is Worse, supra note 102.

123 Larsen, supra note 96.

$124 I d$

125 See id.

126 See Alix Iris Cohen, Note, Nonconsensual Pornography and the First Amendment: A Case for a New Unprotected Category of Speech, 70 U. MiAMI L. REV. 300, 304 (2015).

127 U.S. Const. Amend. I. 
limits the government's ability to create laws addressing "potentially harmful conduct" as it relates to speech where it would not face such limitations regarding the same harmful conduct otherwise. ${ }^{128}$ Laws restricting speech are analyzed under "intermediate" scrutiny or "strict" scrutiny, and "the operating assumption is that any harm that might result from speech is less serious than the harm that results from government restrictions on it." 129 A commonly repeated phrase, "the truth hurts," is often referred to when morally questionable speech is considered protected, as "speech that hurts due simply to the disgust or offense it causes" is generally afforded constitutional protection. ${ }^{130}$ It has been said that "the point of all speech protection ... is to shield just those choices of content that in someone's eyes are misguided, or even hurtful;" and thus, "speech does not lose its protected character... simply because it may embarrass others." $" 131$

Determining whether speech is protected "involves weighing the free speech interests involved in a particular case against other countervailing interests, such as the public or state interests in order and security and the interests in deferring to legislative judgment." Essentially, courts weigh how much the type of speech contributes to free speech values against the harm the speech causes. If the harm caused is great, and the speech contributes only minimally to the underlying purposes of the First Amendment (creating a marketplace of ideas, facilitating participatory democracy, or advancing autonomy), it may be deemed an unprotected category. ${ }^{132}$

However, "the right to free speech is not absolute at all times and under all circumstances," as courts have recognized categorical exceptions to which First Amendment protections do not extend and consequently, "the government can regulate the speech with more or less the same broad level of discretion and flexibility that applies in regulating non-speech conduct."133 Among these exceptions are defamation and child pornography. ${ }^{134}$ Similarly, courts have found that other forms of speech

128 John A. Humbach, The Constitution and Revenge Porn, 35 PACE L. REV. 215, 219 (2014).

129 Id. at 220.

130 Clay Calvert, Revenge Porn and Freedom of Expression: Legislative Pushback to an Online Weapon of Emotional and Reputational Destruction, 24 FordHAM INTELL. PROP. MEDIA \& ENT. L.J. 673, 674 (2014).

131 Humbach, supra note 128, at 233.

132 Cohen, supra note 126, at 311.

133 Humbach, supra note 128, at 220, 235.

134 Id.; see also Calvert, supra note 130, at 675. 
have "enjoyed less rigorous protection as a historical matter, even though they have not been recognized as such explicitly."135 Accordingly, with respect to revenge porn laws, there are two known conflicting views: (1) revenge porn constitutes protected speech, and thus laws banning it trigger First Amendment concerns, and (2) revenge porn does not, or should not, constitute protected speech, and thus revenge porn laws are constitutional. $^{136}$

Content-based restrictions are those that "burden or restrict speech based on its subject matter or on the viewpoint that is expressed," as opposed to content-neutral regulations that regulate "merely the time, place and manner of expression, without regard to the ideas, facts or message expressed" or those "meant to address the... 'secondary effects' of speech." 137 The Supreme Court has expressed a willingness to balance harms when determining whether content-neutral restrictions are unconstitutional, whereas "it has been almost unbending in its protection of speech from content discrimination," and considers "content-based regulations presumptively invalid." 138 Also, content-based regulations must pass "strict" scrutiny (i.e. the government must have enacted the law to further a compelling governmental interest and the law must be the least restrictive means to further that interest), unless an exception applies. ${ }^{139}$

\section{ARGUMENTS ABOUT UNCONSTITUTIONALITY}

First, "posting nude or explicit images of former lovers online" is speech. ${ }^{140}$ And, as regulations aiming to suppress disfavored speech (i.e. the revenge porn itself), they are content-based speech. ${ }^{141}$ Accordingly, opponents argue that revenge porn laws face an uphill battle with regard to the First Amendment and strict scrutiny review, unless the particular law falls within the scope of an exception. ${ }^{142}$ While the issue of "whether nonconsensual pornography is protected speech," has never been before the

135 Danielle Citron, Debunking the First Amendment Myths Surrounding Revenge Porn Laws, FORBES (Apr. 18, 2014, 11:19 AM), http://www.forbes.com/sites/daniellecitron/2014/04/18/debunkingthe-first-amendment-myths-surrounding-revenge-porn-laws/\#a95f5d44b894.

136 See generally Cohen, supra note 126, at 305-06; Humbach, supra note 128, at 217.

137 Humbach, supra note 128, at 222.

138 Id.

139 KATHLEEN ANn RuAne, CONG. ReSEARCH SERV., 95-815, FreEdOM OF SPEECH AND PreSs: EXCEPTIONS TO THE FIRST AMENDMENT 1, 5 (2014), https://www.fas.org/sgp/crs/misc/95-815.pdf.

140 Mark Bennett, A Better Revenge-Porn Statute, DefEnding People (Oct. 26, 2013), http://blog.bennettandbennett.com/2013/10/a-better-revenge-porn-statute/.

141 See Humbach, supra note 128, at 221.

142 Id. at 234-35. 
Supreme Court, ${ }^{143}$ if the Supreme Court were to determine that revenge porn does not fit squarely into one of the existing categories or exceptions, case law suggests that the Court is unlikely to create a new category for it. ${ }^{144}$ The Court's willingness to do so seems limited to "only where the speech historically has been unprotected but not yet addressed by the Court," and "revenge porn, of course, is a new form of expression for which there is no historical lack of protection." "145 As a general matter, critics of revenge porn laws have stated that "[c]riminalizing the distribution of that which was freely given and freely received would be invalidated under the First Amendment," as "the First Amendment is not the guardian of taste." More specifically, opponents of revenge porn laws argue that nonconsensual pornography is protected speech, as it does not fall into any of the established exceptions, and more importantly, that courts are unwilling to expand these exceptions for content-based regulations such as revenge porn. ${ }^{147}$

Opponents argue that the government does not have an interest, let alone a compelling interest, in withholding "a truth" from others because such dissemination of that truth causes an "individualized harm" rather than a "social harm." "148 The underlying argument is that society is unharmed by the distribution of revenge porn, despite the harm it causes the individual depicted in the images, but rather "society" (e.g. employers) has an interest in this information when deciding who to hire, or keep, as an employee, given that the "information" is available. ${ }^{149}$ Because "people may especially want to know what others have done of which they are not especially proud," preventing the availability of this information would cause harm to people's interest "in knowing who among us strays beyond the bounds of the law or morality." 150 Thus, as opponents argue, despite the very real and recognized harm that revenge porn causes its victims, it is only harming that individual; and, therefore, the individualized harm falls short in the eyes of the Constitution, which "assumes that there would be even greater harm in criminalizing the free flow of information concerning the activities that it reveals." 151

\footnotetext{
143 Cohen, supra note 126, at 312.

144 Larsen, supra note 96.

145 Id
}

146 Erin Fuchs, Here's What the Constitution Says About Posting Naked Pictures of Your Ex to the Internet, BUS. INSIDER (Oct. 1, 2013, 1:08 PM), http://www.businessinsider.com/is-revenge-pornprotected-by-the-first-amendment-2013-9.

147 See Humbach, supra note 128, at 235-36.

148 See id. at 231.

149 See id. at 226-30.

150 Id. at 227.

151 Id. at 230. 


\section{ARGUMENTS THAT IT IS CONSTITUTIONAL}

Proponents of revenge porn laws argue revenge porn is not considered protected speech, and therefore falls outside the purview of First Amendment protections, because it relates to a known exception or should be considered a new exception. ${ }^{152}$ The crux of the argument is that "revenge porn should receive, at most, de minimis First Amendment protection" because it exists "merely to humiliate its victim; it does not inform public debate, nor is it a form of artistic self-expression." 153 Generally, pornography is considered protected speech so long as "the sexually explicit images neither constitute obscenity nor child pornography." 154 As such, proponents argue that non-consensual pornography plausibly fits into the category of "obscenity" or as variation of child pornography. ${ }^{155}$ Proponents of criminalization also argue that, as public disclosure of a private fact, it deserves less rigorous First Amendment protection. ${ }^{156}$

\section{OBSCENITY}

In Miller v. California, the Supreme Court held that "obscenity" does not enjoy First Amendment protection and, proponents argue, sexually intimate images distributed without consent of the individual depicted fit this category. ${ }^{157}$ In Miller, the Court lists basic guidelines for determining whether material constitutes obscenity:

(a) whether "the average person, applying contemporary community standards" would find that the work, taken as a whole, appeals to the prurient interest[;] (b) whether the work depicts or describes, in a patently offensive way, sexual conduct specifically defined by the applicable state law; and (c) whether the work, taken as a whole, lacks serious literary, artistic, political, or scientific value. ${ }^{158}$

152 See generally Cohen, supra note 126, at 300 (arguing for a new categorical exception for nonconsensual pornography so that it will not be protected by the First Amendment).

153 Paul J. Larkin Jr., Revenge Porn, State Law, and Free Speech, 48 LoY. L.A. L. REV. 57, 113 (2014) (emphasis added).

154 Cohen, supra note 126, at 312.

155 Why We Need a Federal Criminal Law Response to Revenge Porn, supra note 105.

156 See generally Cohen, supra note 126, at 314-21.

157 Miller v. California, 413 U.S. 15, 23 (1973); Larsen, supra note 96.

158 Miller, 413 U.S. at 24. 
Proponents argue that because revenge porn depicts sexual activity without the consent of the person depicted, it, arguably, appeals to the prurient interest. ${ }^{159}$ Additionally, revenge porn may qualify as "patently offensive" sexual conduct given the depicted individual's lack of consent and the "potentially secretive nature of the exposure of the photographs and videos." "160 Finally, revenge porn's nonconsensual component may also contribute to an argument that such content "lacks serious literary, artistic, political, or scientific value." 161 Thus, a law banning revenge porn that specifically excludes material of public interest would likely survive constitutional inquiry. ${ }^{162}$

\section{VARIATION OF CHILD PORNOGRAPHY}

Child pornography consists of "pornographic materials featuring sexual conduct by children." 163 Supporters of revenge porn laws reason that even though adult pornography is generally afforded First Amendment protection, the "nonconsensual nature of revenge porn makes it rise to the same level of offensiveness as child porn: because it is nonconsensual, distributing revenge porn inflicts greater harm on victims than consensual pornography, outweighing its marginal free speech value."164 Therefore, pornography that is distributed or publicized without consent of the person depicted, should be considered a category of unprotected speech. ${ }^{165}$

\section{PUBLIC DisClosuRE OF A PRIVATE FACT}

Similarly, proponents argue that nonconsensual pornography should be unprotected speech as a public disclosure of a private fact, which has been afforded less rigorous First Amendment protection. ${ }^{166}$ The likelihood of obtaining First Amendment protection when a particular truth is neither regarding a public concern nor political in nature, decreases significantly. ${ }^{167}$ The most common definitions of the public disclosure of a private fact tort include the following elements: (1) the public disclosure, (2) of a private

159 Samantha H. Scheller, Comment, A Picture is Worth a Thousand Words: The Legal Implications of Revenge Porn, 93 N.C.L. REV. 551, 570 (2015).

$160 \quad I d$.

$161 \quad I d$.

162 Larsen, supra note 96.

163 Cohen, supra note 126 , at 327.

164 Id. at 331-32.

165 Id. at 332.

166 See generally id. at 314-21.

167 Calvert, supra note 130, at 675. 
fact, (3) that would be offensive and objectionable to a reasonable person, and (4) that is not of legitimate public concern. ${ }^{168}$

A disclosure of a private fact is public "if the communication is made to a large or potentially large group of people."169 Both when the "communicator distributes the private information to the large group of people himself or herself," and when the "communicator merely initiates the process whereby the information is eventually disclosed to a large number of persons," a public disclosure has taken place. ${ }^{170}$ Disclosure includes oral and written communications, video, or still photographs. ${ }^{171} \mathrm{~A}$ fact is private if there is a reasonable expectation of privacy in the fact(s), and as such, is not already "a matter of public record." "172 In general, public disclosure of private fact is not protected by the First Amendment because, when balanced, the free speech value is minimal compared to the drastic harm that results. ${ }^{173}$ Moreover, when the communication is in the form of an image or video, rather than verbal, the communicator's ability to distribute information increases significantly simply because of the primitive truth that "a picture is worth a thousand words.", "174

Courts have held that a nonconsensual publication of sex videos constitutes public disclosure of private fact. ${ }^{175}$ For instance, in Michaels $v$. Internet Entertainment Group, Inc., the court enjoined the publication of a sex tape of Pamela Anderson and Bret Michaels by a company that obtained the footage "because the public had no legitimate interest in graphic depictions of the 'most intimate aspects of' a celebrity couple's relationship." 176 The court reasoned that a sex tape depicting two people engaged in sexual relations "represents the deepest possible intrusion into private affairs." $" 177$

Similar to Michaels, in cases of nonconsensual pornography that revenge porn laws seek to prevent, the public has no legitimate interest in private nude photographs and sex tapes that the depicted person has not consented to be distributed. ${ }^{178}$ Furthermore, to the extent exceptions have been carved out for child pornography and defamation due to grave harms

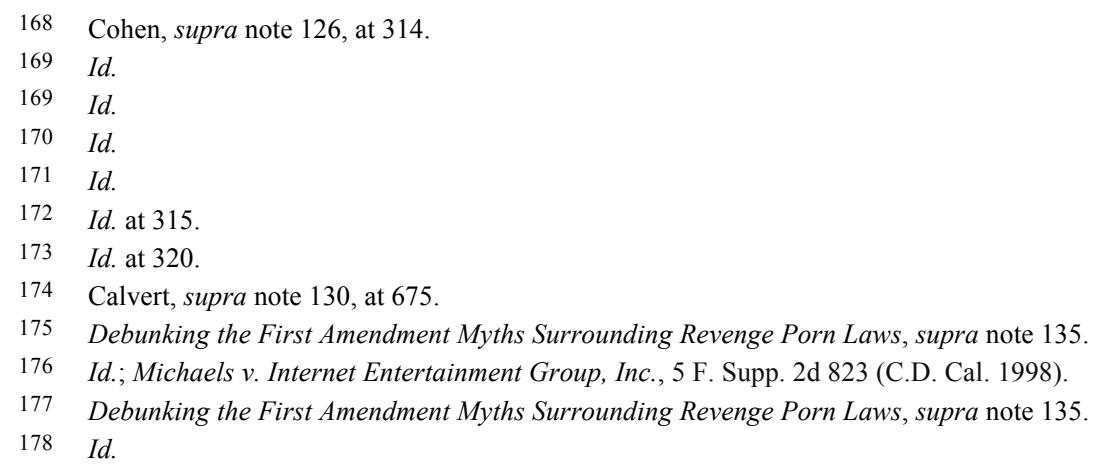


far exceeding the speech's advancement of "free speech values," 179 so, too, do the harms caused by revenge porn (e.g. violation of sexual privacy, loss of employment, loss of educational opportunities, and psychological trauma $)^{180}$ far outweigh its free speech value.

\section{CRIMinaliZation IS NeCESSARY}

Assuming that a criminal revenge porn statute could withstand constitutional muster, opponents argue that such statutes will be essentially useless. ${ }^{181}$ The enactment of a valid state statute banning revenge porn does not necessarily equate to the police actively enforcing it or, at minimum, informing victims of its existence. ${ }^{182}$ Cases have been noted where multiple women, who have called the police to report victimization, were told by police that revenge porn - "the posting of nude photos"-was not illegal, despite existing laws in that state clearly stating it was. ${ }^{183}$ Others argue that, oftentimes, judges give minimal sentences to more physically intrusive sexual crimes, such as rape and sexual assault, which leads to the conclusion that they are even less likely to take a violation of a revenge porn statute seriously. ${ }^{184}$ Another argument is that, given the rapid spread of revenge porn content, prosecuting every perpetrator would prevent prosecutors from devoting the necessary time and energy to prosecuting the more serious crimes. ${ }^{185}$ One attorney noted, "Look at UGostPosted.comthere are probably 5,000 women and men on there. What are they going to do? Open up 5,000 criminal files?"186

Proponents, on the other hand, argue that because of the continued growth of technology and the Internet, coupled with the "heightened sexualization of younger generations," revenge porn will not only never go away, but will likely become an even graver problem. ${ }^{187}$ As is the case with any other crime, making revenge porn illegal is the only approach that will deter both the posters and the website hosts from the undesirable conduct in the first place. ${ }^{188}$ Not only are civil remedies insufficient to redress victims

\footnotetext{
179 See generally Cohen, supra note 126, at 324-32.

180 Why Revenge Porn Must be a Crime: Dissecting Critics' Attempts to Nitpick Important Legislation, supra note 70.

181 Larsen, supra note 96.

182 Hayley Fox, Why Revenge Porn Laws May Not Protect Women, TAKEPART (Dec. 2, 2014), http://www.takepart.com/article/2014/12/02/revenge-porn-protections.

183 Id.

184 Larsen, supra note 96.

185 Id.

186 Id.

187 See Robertson, supra note 110.

188 Id.
} 
of their harms, but "the kinds of people who post or traffic in revenge porn don't worry about being sued; they do worry about going to jail."189 The spiteful ex-boyfriends and website hosts will then have to weigh the satisfaction they expect to gain from posting the images against facing criminal punishment and a criminal record. ${ }^{190}$ Thus, they have to ultimately decide whether posting the images is "worth it," hopefully to be answered in the negative. ${ }^{191}$ Deterrence is not only necessary because of the wideranging psychological ramifications revenge porn causes its victims, but also because it endangers the lives of those who fall prey to revenge porn that includes identifying information alongside the images. ${ }^{192}$

Despite the heavy opposition to legislation criminalizing revenge porn, there is a general consensus that these laws are becoming more necessary than ever before. However, many of these laws have been deemed ineffective and federal courts have even blocked state revenge porn laws from enforcement because their constitutionality has been called into question. ${ }^{193}$ Arizona's revenge porn law, for example, made it a felony to "disclose, display, distribute, publish, advertise or offer" an image of a nude person without the depicted person's consent. ${ }^{194}$ The statute was drafted with the intent to target and prevent specific situations, such as vengeful exes spreading their prior lover's intimate photographs. ${ }^{195}$ However, "a group of Arizona booksellers, publishing companies, newspapers, librarians, and photographers (including the Voice Media Group, New Times' parent company)" responded by suing the state Attorney General's Office ("AGO"). ${ }^{196}$ They argued that the law, as drafted, was "unconstitutionally overbroad and [was] [a] viewpoint-based restriction on protected speech" because it criminalized unintended scenarios that are constitutionally protected, such as "a library lending a photo book about breastfeeding to a new mother, a newspaper publishing pictures of abuse at the Abu Ghraib prison, or a magazine running a story about a local art show." ${ }^{197}$ Accordingly, the law was halted for being over-inclusive. ${ }^{198}$ The

189 Why Revenge Porn Must be a Crime: Dissecting Critics' Attempts to Nitpick Important Legislation, supra note 70.

190 Robertson, supra note 110.

191 Id.

192 Larsen, supra note 96.

193 Town-Crier Editor, New 'Cyber-Harassment' Law is Needed, But Might Be Too Broad, TOWN-CRIER ONLINE (Oct. 9, 2015, 12:02 AM), http://gotowncrier.com/2015/10/new-cyberharassment-law-is-needed-but-might-be-too-broad/.

194 Id

195 Miriam Wasser, AZ Revenge Porn Law Not to be Enforced, Says Federal Judge, PHX. NEW TIMES (July 13, 2015, 2:45 PM), http://www.phoenixnewtimes.com/news/az-revenge-porn-law-not-tobe-enforced-says-federal-judge-7486054.

196 Id.

197 Id.; Town-Crier Editor, supra note 193. 
AGO recognized the law was unenforceable as written and, in agreeing to settle the case after conceding that there were legitimate constitutional concerns, the AGO hoped to avoid further litigation and incentivized legislators to amend the statute by addressing those concerns. ${ }^{199}$

Therefore, legislators should proactively amend laws that are constitutionally questionable by including narrower language to avoid overbreadth, as well as including language to ensure the law accomplishes its ultimate goals: providing justice for its victims and preventing future victims. Who knows, revenge porn may eventually be held to the standard of child pornography and defamation, given their vast similarities, and thus may be afforded an explicit exception from the heightened review of strictscrutiny.

\section{FLORIDA'S FAILED ATTEMPTS}

Florida, along with many other states, has considered several bills addressing revenge porn before ultimately passing one that was deemed satisfactory, House Bill $151 .^{200}$ For example, in early 2013, in considering a bill addressing revenge porn, Florida legislators balanced the reality that, if passed, it could be held as unconstitutional for infringing on First Amendment rights, against the strong incentives for criminalizing revenge porn. ${ }^{201}$ The bill would have criminalized, as a third-degree felony:

$[\mathrm{T}]$ he internet posting of a photo or video: of an individual which depicts nudity and contains any of the depicted individual's personal identification information ... without first obtaining the depicted person's written consent unless the victim was photographed or videotaped in public and a lack of objection to the photography or videotaping could reasonably be implied by the victim's conduct. ${ }^{202}$

In analyzing the bill, Florida House of the Representatives noted that "there are no criminal laws ... prohibit[ing] the posting of nude adult photos on the Internet," and that "[a] recent survey found that one in ten people have threatened to expose risqué photos of their ex-partners online, and that these threats were carried out nearly 60 percent of the time."203

\footnotetext{
198 Town-Crier Editor, supra note 193.

199 Wasser, supra note 195.

200 H.B. 151, 2015 Leg., Reg. Sess. (Fla. 2015), https://www.flsenate.gov/Session/Bill/2015/151/

201 Calvert, supra note 130, at 693-94; H.R. 787, 2013 Leg., Reg. Sess. (Fla. 2013), http://www.flsenate.gov/Session/Bill/2013/0787/BillText/Filed/PDF.

202 Calvert, supra note 130, at 693.

203 Id
} BillText/c1/PDF. 
Moreover, they advocated for the bill by emphasizing the level of harm that results from revenge porn, namely, that "lives can be destroyed" and that it has already "driven some people to suicide."204 However, the House also noted that " $[\mathrm{t}] \mathrm{o}$ the extent that the bill regulates content of speech protected by the First Amendment, it could be challenged as being unconstitutional. $" 205$

Similarly, Florida House Bill 475, which failed on May 2, 2014, provided that:

An individual may not intentionally and knowingly disclose a sexually explicit image of an identifiable person or that contains descriptive information in a form that conveys the personal identification information ... of the person to a social networking service or a website, or by means of any other electronic medium, with the intent to harass such person, if the individual knows or should have known that the person depicted in the sexually explicit image did not consent to such disclosure.

[A]n individual who violates this section commits a felony of the third degree ... [and] an individual who is [eighteen] years of age or older at the time he or she violates this section commits a felony of the second degree... if the violation involves a sexually explicit image of an individual who was younger than [sixteen] years of age at the time the sexually explicit image was created.

[T] his section does not apply to the disclosure of a sexually explicit image for: (a) the reporting, investigation, and prosecution of an alleged crime for law enforcement purposes, [or] (b) voluntary and consensual purposes in public or commercial settings. ${ }^{206}$

A very similar bill, Florida Senate Bill 532, contained almost identical provisions. However, it made a general violation of the statute a second degree misdemeanor, and a first degree misdemeanor for violators eighteen and over if the image(s) involved a sexually explicit image of someone younger than [sixteen] years old at the time the image was created. ${ }^{207}$

204 Id. at 694.

205 Id. at 693-94.

206 H.B. 475, 2014 Leg., Reg. Sess. (Fla. 2014) (emphasis added), http://www.flsenate.gov/ Session/Bill/2014/475/BillText/Filed/PDF; Aysegul Harika, Note, Banning Revenge Pornography: Florida, 39 NoVA L. REV. 65, 83-84 (2014).

207 Harika, supra note 206, at 84-85. 
Both House of Representatives Bill 475 and Senate Bill 532 required a showing of intent to harass the victim by posting the explicit images. ${ }^{208}$ There is no legitimate basis for distinguishing between perpetrators who disclose private material with intent to harass and those who disclose purely for "entertainment, profit or notoriety." 209 The inclusion of this limitation excludes a pool of victims suffering from the very same harms as those whose perpetrators did have intent to harass. ${ }^{210}$ Accordingly, state legislators' main concern should be the victim's lack of consent, rather than the distributor's motive or intent for distributing the images. ${ }^{211}$ Furthermore, the requirement for a malicious motive generally makes the case harder to prosecute, and, consequently, discourages victims from coming forward, as they are already too ashamed and do not want to risk further publicizing their embarrassing situation. ${ }^{212}$

Additionally, both bills provide that "[a]n individual may not intentionally and knowingly disclose a sexually explicit image of an identifiable person to a social networking service or a website, or by means of any electronic medium." 213 By including the different possibilities where a distributor may choose to post the images, the statute effectively encompasses the many different arenas a distributor may use to achieve his purpose; essentially, the language is staying consistent with current and advancing technology. ${ }^{214}$

Similarly, both bills mention that "[a]n individual may not intentionally and knowingly disclose [a] sexually explicit image of an identifiable person or that contains descriptive information in a form that conveys the personal identification information ... of the person." 215 This disjunctive language seems to indicate that identifying information either beside or linked to the sexually explicit image is not necessary, as the sexually explicit image, standing alone, qualifies so long as it contains identifying information, such as the person's face. This allows a remedy for the victim whose perpetrator does not include demographic information beside the image, but sends a link of the post to family, friends, or employers who recognize the victim's face or other identifying features from the image itself.

\footnotetext{
208 Id. at 86.

209 Why Revenge Porn Must be a Crime: Dissecting Critics' Attempts to Nitpick Important Legislation, supra note 70.

$210 \quad I d$.

211 Id.

212 See Harika, supra note 206, at 87.

213 Id. at 85 (emphasis added).

214 See id.

215 Id. at 84.
} 
The two bills did, however, differ in terms of their degree of punishment for the crime. ${ }^{216}$ Senate Bill 532 would have made a violation a second degree misdemeanor for which "[o]ffenders would face up to 60 days in jail and a $\$ 500$ fine." ${ }^{217}$ House Bill 475 would have made a violation a third-degree felony, which is "punishable by up to five years in prison." 218 The appropriate penalty for a criminal statute may "make or break" a bill regarding its likelihood of being passed. ${ }^{219}$ The appropriate penalty for nonconsensual pornography has been largely debated:

If the conduct is categorized as a mere misdemeanor, it risks sending the message that the harm caused to victims is not that severe. Such categorization also decreases incentives for law enforcement to dedicate the resources necessary to adequately investigate such conduct. At the same time, criminal laws that are more punitive will face stricter examination and possible public resistance. Although California's categorization of revenge porn as a misdemeanor sends a weak message to would-be perpetrators and will be a less effective deterrent than a law like New Jersey's, [which categorizes revenge porn as a felony], it may have aided the law's passage. ${ }^{220}$

Ultimately, Senate Bill 538 outlawing revenge porn was passed nearly unanimously by a $38-2$ vote. ${ }^{221}$ Initially, however, the Senate "sought a tougher version of the bill, which would have included e-mail, but the House passed a more lenient version that only applies to posting pictures on websites." 222

216 Brendan Farrington, Florida Lawmakers Look to Criminalize 'Revenge Porn', FLA. TIMES UNION (Mar. 18, 2014, 6:09 PM), http://jacksonville.com/news/2014-03-18/story/florida-lawmakerslook-criminalize-revenge-porn.

217 Id

218 Id

219 See id.

220 Harika, supra note 206, at 88 (quoting at Citron \& Franks, supra note 17, at 389).

221 Florida Legislature Passes Bill to Make Revenge Porn Illegal, WESH 2 NEws, http://www.wesh.com/news/florida-legislature-passes-bill-to-make-revenge-porn-illegal/32656676 (last updated Apr. 30, 2015, 6:30 AM).

222 Id.; Peter Schorsch, “Revenge Porn” Bill Signed into Law by Governor, FlA. PoL. (May 14, 2015, 5:12 PM), http://floridapolitics.com/archives/183274-revenge-porn-bill-signed-into-law-by-govscott. 


\section{THE CURRENT LAW}

\section{SECTION 784.049, FLA. STAT.}

Subsection (1) of Section 784.049 introduces the law with recognition of the harms nonconsensual pornography causes victims as the legislature's justification for criminalizing the conduct, as well as their compelling interest in redressing these harms. ${ }^{223}$ The first provision states that people have a reasonable expectation that sexually explicit images taken with the depicted person's consent will remain private. ${ }^{224}$ This provision "sets up the expectation that those images of intimate moments are not free to publish anywhere without a person's consent." 225 Next, the statute recognizes the recent growth in nonconsensual pornography by stating that "it is becoming a common practice." 226 Then, the statute addresses the permanent and untraceable effects of having a private, sexually explicit image uploaded onto the internet, as it can be quickly distributed across the world on countless websites. ${ }^{227}$ As a result, the victims suffer "significant psychological harm" and "safeguarding the psychological well-being of persons depicted in such images is compelling."

\section{STRENGTHS OF SECTION 784.049}

While Section 784.049 makes the offense a misdemeanor, rather than a felony, which of course, has less of a deterrent effect on potential offenders, this is likely what allowed the bill to pass. ${ }^{229}$ Specifically, the law provides that, for a first time offender, the offense is punishable as a first degree misdemeanor. ${ }^{230}$ However, the statute increases the degree of punishment to a third degree felony for those who have one prior conviction for sexual cyber-harassment and commit a second offense. ${ }^{231}$

The new law provides law enforcement officers with significant

$223 \S 784.049(1)$, Fla. Stat. (2015).

$224 \S 784.039(1)(a)$, Fla. Stat. (2015).

225 New Florida Law Against Cyber Harassment to Take Effect, PITTMAn FiRM, PA, (Oct. 5, 2015), http://www.pittmanfirm.com/Personal-Injury-Blog/2015/October/New-Florida-Law-AgainstCyber-Harassment-to-Take.aspx.

$226 \S 784.039(1)(b)$, Fla. Stat. (2015).

227 Id. at (1)(c)-(d).

$228 I d$. at (1)(e)-(f).

229 Id. at (3)(a).

$230 \quad$ Id

231 Id. at (3)(b). 
leeway in making their arrests. ${ }^{232}$ A law enforcement officer may arrest, without a warrant, any person that he or she has probable cause to believe has committed sexual cyber-harassment according to the statute. ${ }^{233}$ However, it also serves as a weak spot as those charged with this offense will likely argue the statute violates the Fourth Amendment (regarding unreasonable searches and seizures) of the United States Constitution because of the statute's warrantless search provision. ${ }^{234}$

Another strength of Florida's sexual cyber-harassment law is that the "sexually explicit images" banned from distribution are not limited to those solely depicting nudity. ${ }^{235}$ Section 2(d) defines "sexually explicit image" as "any image depicting nudity ... or depicting a person engaging in sexual conduct." 236 By including images depicting a person engaging in sexual conduct, legislators are appreciating the fact that "not all intimate sexual acts involve nudity." "237 In addition, the statute's definition of "image" includes a non-exhaustive list of image forms that distributors of revenge porn are likely to use, not just the common photograph or video. ${ }^{238}$

At the same time, the law carves out reasonable exceptions, which serve to avoid constitutional concerns that the law is overly broad. The law reasonably excludes internet service providers from potential liability or criminal prosecution. ${ }^{239}$ It also as excludes from its scope sexually explicit images published by law enforcement officers in furtherance of their duties, perhaps for investigational or other public interest purposes. ${ }^{240}$ However, it should have taken the exceptions a step further and excluded images voluntarily exposed by the depicted person in public or commercial settings to avoid unnecessarily including situations where a person has no reasonable expectation of privacy. ${ }^{241}$ Otherwise, unintended prosecutions may occur to such individuals who "forward[ed] or link[ed] to commercial pornography, or [who] record[ed] and report[ed] unlawful activity, such as flashing.'

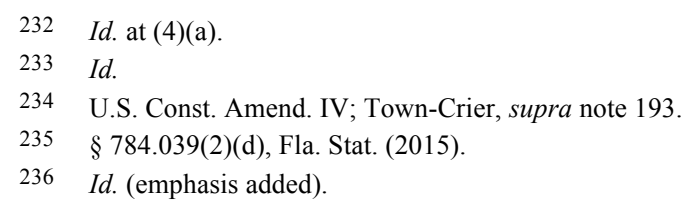

237 Carrie Goldberg, Seven Reasons Illinois is Leading the Fight Against Revenge Porn, CYBER C.R. INITIATIVE (Dec. 31, 2014), http://www.cybercivilrights.org/seven-reasons-illinois-leading-fightrevenge-porn/.

$238 \S 784.039(2)(a)$, Fla. Stat. (2015).

239 Id. at (6)(a).

$240 \quad I d$. at (6)(b).

241 Mary Anne Franks, Drafting An Effective "Revenge Porn" Law: A Guide for Legislators, 1, 5 (Aug. 17, 2015), http://kvenrettindafelag.is/wp-content/uploads/2016/02/Mary-Anne-Franks-_Drafting-an-Effective-Revenge-Porn-Law-08.2015-fylgiskjal.pdf.

242 Id. 
Finally, the law accounts for a civil remedy in addition to imposing criminal punishment. ${ }^{243}$ The statute creates a private cause of action for a victim of revenge porn to bring a private suit against the person responsible. ${ }^{244}$ Specifically, it provides that a victim can obtain injunctive relief; monetary damages up to $\$ 5,000$, or actual damages incurred as a result of a violation, whichever is greater; and reasonable attorney's fees and costs for bringing the case. ${ }^{245}$ Furthermore, "if any conduct that is an element of the offense, or any harm to the depicted person resulting from the offense, occurs within the state," then a violation is deemed to have been committed in Florida. ${ }^{246}$ This provision is also meaningful because of the easy accessibility of the Internet across the United States and the world.

\section{WEAKNESSES OF SECTION 784.049}

The most important provision in the statute is subsection (2)(c), which defines sexual cyber-harassment and contains the details regarding its scope. Section 784.049 defines sexual cyber-harassment as the publishing of a sexually explicit image "that contains or conveys the personal identification information of the depicted person to an Internet website without the depicted person's consent ... with the intent of causing substantial emotional distress to the depicted person."

First, the law is weak to the extent that it includes an element requiring the conveyance of "personal identif[ying] information." 248 The original Senate bill, for example, required the image to include either personally identifying information (plus the victim's face) or just the victim's face, rather than requiring them to simultaneously exist. ${ }^{249}$ Requiring "identifying information" limits the breadth and purpose of the law by allowing offenders to bypass it, once again, even while exposing the victim's face in their post, which is probably the most identifying information a person can have, when viewed in isolation, superior to the victim's name or contact information. ${ }^{250}$ Nonetheless, this provision gives perpetrators the green light—so long as the exposure does not include a

$243 \S 784.039(5)$, Fla. Stat. (2015).

244 Id.

245 Id. at (5)(a)-(c).

$246 I d$. at (7) (emphasis added).

247 Id. at (2)(c).

248 Id.

249 Kyle Munzenrieder, Watered Down Revenge Porn Law Passes Florida Legislature, MiAMI NEw TIMES (Apr. 30, 2015, 12:45 PM), http://www.miaminewtimes.com/news/watered-down-revengeporn-law-passes-florida-legislature-7584179.

250 Francesca Amiker, Revenge Porn Ban Becomes Law, News 4 JAX (Oct. 1, 2015, 7:19 AM), http://www.news4jax.com/news/local/revenge-porn-ban-becomes-law. 
name or address beside it, the perpetrators are in the clear-which sends the wrong message.

Second, the statute is limited to images "publish[ed] . . . to an Internet website," thereby excluding the dispersing of images via text messages, email, or hard copies-which remain legal. ${ }^{251}$ Thus, a victim who had her intimate photographs sent to her family, friends, or employers directly through e-mail or text would not find a remedy in this new law, notwithstanding the damages suffered are much like that of the victim whose images were posted on the Internet, if not worse.

Third, although a good law needs to be narrowly tailored to withstand constitutional muster, the limiting language substantially handicaps prosecutors and excludes innumerable scenarios from falling within the scope of the statute. First, the statute requires the offender to have possessed the specific intent to cause substantial emotional distress, both for a criminal prosecution and a civil suit. ${ }^{252}$ However, other motives may exist that are equally damaging to the victim. ${ }^{253}$ In fact, many offenders "do not know their victims at all." 254 For example, in the case of nude celebrity images that are hacked and shared, ${ }^{255}$ the offender may be motivated by something other than harming the victims, such as notoriety or financial gain, ${ }^{256}$ yet those intentions fall outside the bounds of the law. A patrol officer who passed around intimate photographs that he pulled from a female arrestee's cellphone, which he claims he had done a "half dozen times in the last several years," as part of a "game" among officers, would also not be held criminally liable under this law. ${ }^{257}$ Similarly, when the Penn State chapter of a fraternity was discovered to have been posting images of unconscious, naked women to a private Facebook page that only members had access to, a fraternity brother, in their defense, stated that their conduct "wasn't malicious whatsoever. It wasn't intended to hurt

$251 \S 784.039(2)(c)$, Fla. Stat. (2015).

252 Id.

253 See Why Revenge Porn Must be a Crime: Dissecting Critics' Attempts to Nitpick Important Legislation, supra note 70.

254 How to Defeat 'Revenge Porn:' First, Recognize It's About Privacy, Not Revenge, supra note 69.

255 Laurele O'Connor, Celebrity Nude Photo Leak: Just One More Reminder that Privacy Does Not Exist Online and Legally, There's Not Much We Could Do About It, Golden Gate U. L. ReV. BLOG (Oct. 21, 2014), http://ggulawreview.org/2014/10/21/celebrity-nude-photo-leak-just-one-morereminder-that-privacy-does-not-exist-online-and-legally-theres-not-much-we-can-do-about-it-2/.

256 Why Revenge Porn Must be a Crime: Dissecting Critics' Attempts to Nitpick Important Legislation, supra note 70.

257 How to Defeat 'Revenge Porn:' First, Recognize It's About Privacy, Not Revenge, supra note 69; Matthias Gafni, Warrant: CHP Officer Says Stealing Nude Photos from Female Arrestees 'Game' for Cops, E. BAY TIMES (Oct. 24, 2014, 3:00 PM), http://www.eastbaytimes.com/2014/10/24/warrantchp-officer-says-stealing-nude-photos-from-female-arrestees-game-for-cops/. 
anyone. It wasn't intended to demean anyone. It was an entirely satirical group and it was funny to some extent." ${ }^{258}$ Perhaps he is right, and the fraternity brothers did not "intend to harass or distress the victims." 259 In fact, they were likely "incentivized to avoid the victim's discovery of such conduct altogether, ${ }^{, 260}$ but that should not make the harms of these women any less valuable in terms of their access to the law. All in all, a person, regardless of their sexual promiscuity, should be able to decide who sees them naked. ${ }^{261}$

Such requirements misunderstand the gravamen of the wrong - the disclosure of someone's naked photographs without the person's consent and in violation of their expectation that the image be kept private.... What is essential is a statute's goal of protecting privacy, autonomy, and the fostering of private expression, which the Court has recognized as legitimate grounds for regulation. ${ }^{262}$

Not only does this provision miss the point, but it also makes the law substantially more difficult to prosecute than it would without an intent component. ${ }^{263}$ Prosecutors have to "prove beyond a reasonable doubt that the defendant posted the photo to intentionally hurt the victim," and not because he just thought it was "profitable," "just for fun," to annoy, or any other reason the offender can come up with. ${ }^{264}$

All in all, section 784.049 is both too broad in some aspects and too narrow in others. It is too broad to the extent it does not carve out exceptions for images voluntarily exposed by the depicted person in public or commercial setting. ${ }^{265}$ It is too narrow because the provision limiting the crime to perpetrators with the specific intent to harass the victim fails to encompass many of the victims who are being harmed. ${ }^{266}$ The law is also narrow in its limitation to distributions made on the Internet and its requirement that posts include the victim's identifying information. The law should be amended to eliminate these weaknesses to accomplish the

258 Drafting An Effective “Revenge Porn” Law: A Guide for Legislators, supra note 241, at 6.

259 Id.

$260 \quad I d$

261 Carolina A. Miranda, Hulk Hogan Verdict Raises Crucial Privacy Issues in the Digital Age, L.A. TIMES (Mar. 20, 2016, 3:00 AM), http://www.latimes.com/entertainment/la-et-cam-hulk-hoganprivacy-20160320-story.html.

262 Harika, supra note 206, at 86.

263 Hayley Fox, Why Revenge Porn Laws May Not Protect Women, TAKePART (Dec. 2, 2014), http://www.takepart.com/article/2014/12/02/revenge-porn-protections.

264 Id.

265 See Why Revenge Porn Must be a Crime: Dissecting Critics' Attempts to Nitpick Important Legislation, supra note 70.

266 See id. 
purpose of its enactment, as well as to survive the challenges those charged under this law will surely bring when it is actively enforced.

\section{AN EXEMPLARY LAW: ILLINOIS}

Illinois passed a law banning "nonconsensual dissemination of private images," which became effective June 1, 2015, and has been regarded as "the country's strongest anti-revenge-porn legislation yet." 267 The law addresses many of the concerns discussed above and can serve as an example for Florida legislators in amending its current sexual cyberharassment law. First, in its statute, Illinois legislators did not include language requiring an intent to harass or cause emotional distress to the victim. $^{268}$ In declining to do so, the legislators correctly prioritized the victims of nonconsensual pornography over the perpetrator's motive for distributing the image(s), and Florida should do the same. ${ }^{269}$ If, perhaps because of administrative pressure, Florida legislators are obligated to include an intent to harm or distress the victim, they should consider making it in the form of an objective standard, such as "when a reasonable person would know that such disclosure would cause harm or distress."270

Moreover, the Illinois law includes a provision that excludes the distribution of any images involving "voluntary exposure in public or commercial settings" and when it "serves a lawful public purpose.",271 While Florida's sexual cyber-harassment law includes exceptions for Internet service providers and other unintended entities, and for law enforcement officers who publish sexually explicit images in connection with their duties, ${ }^{272}$ it should include an additional exception for images depicting voluntary exposure in public or commercial settings. In doing so, the law is excluding unintended distributions from its scope, which avoids claims of overbreadth.

Furthermore, the Illinois law applies when a victim is identifiable "from the image itself" (i.e. includes his or her face) or when other

267 Barbara Herman, Illinois Passes Revenge Porn Law with Teeth: "Other States Should Copy, " Says Privacy Lawyer, INT'L Bus. TIMES (Jan. 6, 2015, 4:15 PM), http://ibtimes.com/illinoispasses-revenge-porn-law-teeth-other-states-should-copy-says-privacy-lawyer-1774974.

268 See generally 720 ILL. COMP. STAT. 5/11-23.5 (2015), http://www.ilga.gov/legislation/ publicacts/fulltext.asp?Name=098-1138.

269 Carrie Goldberg, Seven Reasons Illinois is Leading the Fight Against Revenge Porn, CYBER C.R. INITIATIVE (Dec. 31, 2014), https://www.cybercivilrights.org/seven-reasons-illinois-leading-fightrevenge-porn/.

270 Drafting An Effective "Revenge Porn" Law: A Guide for Legislators, supra note 241, at 7.

271720 Ill. COMP. STAT. 5/11-23.5 (c)(3)-(4) (2015).

$272 \S 784.049$ (6)(a)-(b), Fla. Stat. (2015). 
information is displayed in connection with the image. ${ }^{273}$ Florida should also include this disjunctive language, as opposed to only providing for images including identifying information. Accordingly, it will avoid providing loopholes for offenders to still post the image knowing they will not be prosecuted if they exclude identifying information.

\section{CONCLUSION}

"A few years ago, having your compromising photos fall into the wrong hands was a nightmare scenario. Now it's a genre." 274 While this is true, state legislatures, including Florida, have finally come to terms with this truth and have enacted legislation to combat revenge porn. The extent of the harms victims suffer as a result of these malicious acts are finally being recognized and they are being afforded recourse in the criminal justice system as well as civil courts. These laws are enacted with the primary and important purpose of, at minimum, deterring people from contributing to the Internet websites currently making fortunes from exploiting victims' nude photographs on the universe that is the Internet; as well as across virtually all forms of social media that have become such a prevalent source of information in today's society.

In its short time as an enacted law, section 784.049 has served, at minimum, to bring more awareness regarding revenge porn and notice that it is something to be taken seriously. In Florida, in March 2016 alone, at least two cases with revenge porn-related issues have been won by victims, although not under the new law because the conduct preceded its enactment. A Florida victim's overly possessive ex-boyfriend of several years who posted photographs and videos he took of her when she was only sixteen years old accepted responsibility for spreading the "revenge porn" that caused the victim so much harm. ${ }^{275}$ She did consent to some of the nude photographs at the time they were taken, which was during the time she was underage, but many of the photographs and some of the videos were secretly recorded without her consent. ${ }^{276}$ When they eventually broke up, he began sending her coworkers friendship requests from Facebook and Instagram profiles that displayed her nude images (as many as sixty-two), and even attempted forty times to post the nude images on her employer's

273720 ILL. COMP. STAT. 5/11-23.5 (b)(1)(B).

274 Tsoulis-Reay, supra note 40.

275 David Ovalle, “Revenge Porn” Nets Miami Beach Man 30 Days Jail, 5 Years' Probation, Miami HERALD (Mar. 18, 2016, 12:52 PM), http://www.miamiherald.com/news/local/community/ Miami-dade/Miami-beach/article66871647.html.

$276 \quad I d$. 
Facebook page. ${ }^{277} \mathrm{He}$ admitted to video voyeurism and took a plea deal "agreeing to spend 30 days in jail, complete five years of probation, and pay $\$ 2,500$ each to the national program Cyber Civil Rights Initiative and Project Phoenix, a shelter for human trafficking victims at Miami's Camillus House." 278 Because victims are starting to realize that their harm has a place in the justice system, victims, like her, are encouraged to come forward with their story and prosecute these crimes. ${ }^{279}$

Similarly, a Florida jury recently awarded Terry Bollea, a famous wrestler also known as Hulk Hogan, \$115,000,000 when a video of him having sex with his friend's wife was published without his consent on a website. $^{280}$ While much of the case concerned issues surrounding media and celebrity privacy, at its core was the privacy concern underlying revenge porn laws: lack of consent. ${ }^{281}$ The hefty verdict serves as further proof that the public's perspective is shifting toward a stronger intolerance for "media invasions of privacy" and that "the public is becoming disenchanted" with claims of freedom of speech protections when it is not merited. ${ }^{282}$

Although a step in the right direction, especially after numerous failed bills, section 784.049, Florida Statute (2016), needs to be reformed to effectively accomplish what the law was set out to. State legislators can carefully and precisely draft a more efficient law that reconciles with the First Amendment while simultaneously providing victims with the best, most efficient protection. While the Florida Senate was wise to accept a more-limited version of the bill they proposed, rather than do nothing at all, ${ }^{283}$ the initial goal of getting the law in books has been accomplished. Now it is time to fine-tune it.

280 Miranda, supra note 261.

281 See generally id.

282 See Edward Helmore, Could Hulk Hogan's \$115m Win Against Gawker Destroy the Gossip Site Forever?, GUARDIAN (Mar. 19, 2016, 4:31 PM), http://www.theguardian.com/media/2016/mar/19/ hulk-hogan-lawsuit-win-takedown-gawker.

283 Sun Sentinel Editorial Bd., “Revenge Porn” Deserves to be a Crime, Sun SENTINAL (May 11, 2015, 6:46 PM), http://www.sun-sentinel.com/opinion/editorials/fl-editorial-revenge-porn-law-dv20150511-story.html. 